\title{
A IDENTIDADE INTOLERANTE NO DISCURSO SEPARATISTA
}

RESUMO: Apresentam-se alguns resultados de um projeto sobre a construção discursiva da identidade intolerante, desenvolvido no âmbito do Laboratório de Estudos sobre a Intolerância, na perspectiva da semiótica discursiva de linha francesa. O objetivo é mostrar como se constroem os discursos intolerantes (racista, fascista, separatista) e qual a identidade, o ethos intolerante que neles se cria. Para tanto, são examinados os procedimentos linguísticodiscursivos usados e o quadro de valores em que esses discursos se colocam. Este artigo trata ainda de um tipo de discurso intolerante, o separatista.

PALAVRAS-CHAVE: Discurso intolerante; discurso separatista; ethos do enunciador; semiótica discursiva.

\section{CONSIDERAÇÕES INICIAIS}

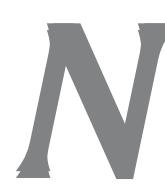

este artigo apresentamos alguns resultados de um exercício de análise do discurso separatista no âmbito de um projeto mais amplo sobre os procedimentos de construção da identidade intolerante nos discursos, desenvolvido no quadro de estudos sobre a intolerância e o preconceito linguíísticos no Laboratório de Estudos sobre a Intolerância (LEI). O objetivo desse projeto geral é mostrar como se constroem os discursos intolerantes (racista, fascista, separatista etc.) e qual a identidade, o ethos intolerante que se cria nesses discursos. Para tanto, serão examinados os procedimentos linguí́stico-discursivos usados

Universidade de São Paulo e Universidade Presbiteriana Mackenzie/CNPq. 
nos discursos e o quadro de valores em que esses discursos se colocam.

Este trabalho retoma e trata especificamente de um tipo de discurso intolerante, o separatista, e desenvolve dois estudos anteriores: um que apresenta algumas hipóteses gerais sobre o discurso intolerante, propostas segundo a perspectiva da semiótica discursiva de linha francesa (Barros, 2005); o outro que examina o discurso separatista gaúcho (Barros, 1992), na mesma linha teórica, a partir do livro de Irton Marx (1990), Vai nascer um novo país: República do Pampa Gaúcho. O livro reúne textos diversos do autor, alguns anteriormente publicados.

A escolha do discurso separatista deveu-se a duas razões principais: ao fato de ele ter sido já examinado por nós, embora com outros objetivos, e ao fato de nele se cruzarem diferentes formas de intolerância - racista, separatista, linguiística, etc -, como pudemos observar no trabalho anterior citado. Realmente, o discurso separatista é também um discurso racista (gaúchos vs. sertanejos) e de intolerância linguiística.

A relação estreita entre as várias formas de intolerância (racial, religiosa, social, política, socioeconômica, linguiística) é, sem dúvida, uma das características gerais dos discursos intolerantes. Essas relações são geralmente hierarquizadas, ou seja, há uma forma de intolerância de base, predominante, a que se subordinam as demais, como, por exemplo, ocorre no Brasil no caso do preconceito racial em relação aos negros, que pode ser considerado uma intolerância primária, em relação às intolerâncias quanto ao modo de falar dos negros, à sua religião etc.

Este artigo organiza-se em duas partes: a primeira, com algumas hipóteses gerais sobre a construção dos discursos intolerantes e com a noção de ethos, na perspectiva semiótica; a segunda, com o exame do discurso separatista. 


\section{ALGUMAS HIPÓTESES SOBRE A CONSTRUÇÃO DOS DISCURSOS INTOLERANTES}

Em estudo anterior (Barros, 2005), estabelecemos algumas hipóteses de análise que são agora retomadas para o caso específico do discurso separatista gaúcho: exame narrativo dos discursos intolerantes, para a elaboração da ou das organizações narrativas que caracterizam esses tipos de discursos; exame da modalização e da aspectualização, para a constituição dos percursos passionais dos discursos intolerantes; exame das categorias de pessoa, de tempo e de espaço, para o estabelecimento das relações de aproximação e distanciamento entre o discurso intolerante e as instâncias de sua enunciação, e entre enunciador e o enunciatário do discurso; exame dos temas e figuras dos discursos intolerantes, para a construção de boa parte do quadro de valores em que esses discursos se inserem e de sua determinação sócio-histórica; exame do plano de expressão, ${ }^{1}$ para a verificação dos recursos sensoriais usados na construção do discurso intolerante; exame dos diálogos que os discursos intolerantes mantêm com outros discursos sociais, para a complementação do quadro de valores em que se coloca o discurso intolerante.

O exame desses procedimentos e estratégias, entre outros, levará à construção da identidade intolerante, do ethos intolerante em geral, e neste estudo, de uma identidade intolerante específica, a do enunciador do discurso separatista. A noção de ethos aqui utilizada foi retomada de Aristóteles e da sua retórica (1991) na perspectiva da semiótica discursiva (ver, sobretudo, Discini, 2003 e Fiorin, 2004):

- o ethos se explica nos textos a partir das marcas da enunciação deixadas no enunciado;

- o ethos do enunciador é a sua imagem construída nos textos como um ator da enunciação e não como um actante da enunciação ou como um autor de carne e osso (Greimas e Cortés, 1979, p. 7-8); o

Neste artigo, por falta de espaço, não serão apresentados os resultados da análise do plano da expressão, nem do exame das categorias de tempo e de espaço. 
BARROS, Diana Luz Pessoa de. A identidade intolerante no discurso separatista

actante, para a semiótica, é uma posição sintática, enquanto o ator é a concretização semântica (temática e figurativa) desse actante;

- deve-se distinguir o ethos do enunciador do ethos do narrador (Fiorin, 2004, p. 122), sendo o ethos do narrador definido por um único discurso, e o do enunciador, por um conjunto, uma totalidade de discursos.

Em síntese, não se trata de apontar autores de carne e osso, mas atores discursivos, construídos em cada discurso e no conjunto deles, e pelo diálogo com outros discursos sociais.

\section{A IDENTIDADE INTOLERANTE NO DISCURSO SEPARATISTA}

\subsection{A narrativa intolerante separatista}

A hipótese que elaboramos é a de que o discurso intolerante é, sobretudo, um discurso de sanção aos sujeitos considerados maus cumpridores de certos contratos sociais (por exemplo, de branqueamento da sociedade, de pureza linguiística) e que, portanto, devem ser reconhecidos como pretos ignorantes, usuários de língua incorreta, índios bárbaros, judeus exploradores, árabes fanáticos, e punidos (com a perda de direitos, de emprego, com a morte). Concebida a narrativa dessa forma, a intolerância dos discursos encontra sua justificativa.

A narrativa separatista (Barros, 1992) vem comprovar essa hipótese e acrescentar novos elementos ao estabelecimento das relações narrativas intolerantes. A narrativa separatista deve ser entendida como uma narrativa de ruptura de contratos entre destinador e destinatário, tal como as narrativas intolerantes em geral, mas também como uma narrativa de resistência à intolerância do outro.

Vejamos, em primeiro lugar, a questão da ruptura de contrato. No caso do discurso separatista gaúcho, o destinador aparece como o Brasil, o governo e os políticos brasileiros e, em última instância, o povo brasileiro, e o destinatário, como os gaúchos ou o povo gaúcho. Há aqui uma primeira especificidade do discurso se- 
paratista em relação aos outros discursos intolerantes. Nos outros casos, o destinador propõe um contrato, por exemplo, de branqueamento da população ou de pureza da língua, e considera que o destinatário - os negros, certos imigrantes, os que escrevem ou falam "mal" - não cumpriu esse acordo e merece, portanto, sanção negativa. No discurso separatista, é o destinatário e não o destinador que interpreta o modo de ser e de fazer do destinador e julga que, embora ele, destinatário, tenha cumprido a sua parte do acordo, o mesmo não ocorreu com o destinador, ou seja, para o povo gaúcho o destinador Brasil não agiu conforme os compromissos com ele assumidos. Essa mudança de papel narrativo do sujeito que sanciona, destinador nos discursos intolerantes em geral e destinatário nos discursos separatistas, tem consequiências na construção discursiva da identidade intolerante.

Nos discursos intolerantes em geral, o destinador é o sujeito do poder que julga e pune o destinatário em falta; nos discursos separatistas, o destinatário põe em dúvida a competência do destinador e contra ele se revolta.

O destinatário julga que o destinador não cumpriu a sua parte no acordo, não tem as qualidades necessárias para honrar o compromisso, não tem, portanto, qualificações para o papel de destinador. Falta ao destinador a competência para cumprir o acordo e assumir o lugar que cabe a um destinador. Entendida a competência como o arranjo de qualidades modais necessárias para que o sujeito faça - o querer-fazer, o saber-fazer e o poder-fazer -, podese dizer que o Brasil e os brasileiros são sujeitos que não querem, não sabem e não podem cumprir os compromissos assumidos com os gaúchos:

Sabemos que durante dezenas de anos nós alimentamos grande parte do Brasil, mas o governo, ao invés de reconhecer este fato, prefere fazer obras e investimentos em regiões cujos povos não possuem um mínimo de tradição em trabalhar e de pensar um pouco mais. São em sua enorme maioria simples predadores, destruidores da natureza e por si só nada fazem ou pouco produzem. Com raras exceções, paira o espectro da preguiça, da falta de vontade, em grande parte do Brasil. (p. 54) 
BARROS, Diana Luz Pessoa de. A identidade intolerante no discurso separatista

Nunca fomos e jamais seremos parasitas, pois produzimos quase tudo de fato e de direito e chegou o momento histórico de pararmos de alimentar ou enriquecer pessoas que nada ou quase nada fazem por si mesmas. Estamos sendo prejudicados há séculos pelos brasileiros em geral. (p. 54)

Nossa realidade é bem outra. Temos uma tradição, uma filosofia de trabalho, de boa vontade e o nosso crescimento se deu pelo esforço, amor, luta e dedicação do nosso próprio povo. (p. 54)

Nós, gaúchos, passamos vergonha ao encararmos os estrangeiros nas nossas ruas, que nos olham com desprezo, como sendo velhacos, incompetentes e ignorantes, sem o poder de ação quando na verdade eles não sabem que o povo gaúcho nada tem a ver com os erros técnicos e a discrepância do governo do Brasil. Os estrangeiros não sabem que somos um povo diferente, que só não somos ainda independentes porque deixamos passar dezenas de anos na esperança que tudo pudesse se modificar de uma hora para outra. (p. 54)

O acordo que o destinador Brasil não cumpre em relação ao destinatário povo gaúcho é, sem dúvida, o que cabe a um destinador justo: o de observar que o destinatário realizou a sua parte do contrato e merece, portanto, o reconhecimento e a recompensa que lhe são devidos. Assim, o povo gaúcho esperava que o Brasil mantivesse o equilíbrio adequado entre as partes que compõem o todo do país, reconhecendo os direitos maiores dos gaúchos, já que são mais qualificados e merecedores de retribuição. Não é dessa forma que o destinatário interpreta o fazer do destinador, mas, ao contrário, julga que ele não realizou a contento seu papel de destinador, pois não sancionou corretamente o povo gaúcho, não reconheceu suas qualidades e não lhe atribuiu a recompensa merecida:

Estamos cansados de promessas incumpridas e não acreditamos em mais nenhuma. Tornamo-nos ateus em relação aos brasileiros. Estamos realmente cansados de mendigar favores de pedir dinheiro que é nosso mesmo. Nossas enormes arrecadações por intermédio dos impostos devem permanecer no local onde ele foi produzido. (p. 55)

A desorganização e a corrupção generalizada por todo território brasileiro, a indiferença para com sua e a nossa gente, nos impelem a tomar uma decisão tão drástica que é o buscar a nossa própria autonomia, resgatando nossa história, firmando-nos como um povo autônomo, que olha o futuro com raro brilhantismo. 
Filol. linguiíst. port., n. 9, p. 147-167, 2007.

\begin{abstract}
Não é justo que paguemos altos preços sociais pela inegável incompetência administrativa do governo e dos políticos do Brasil, bem como, também não é justo que percamos nossas tradições, nossa epopéia de glorias regionais, estamos atrelados a uma nação sem identidade e que não sabe portar-se idoneamente (...).

Ao longo dos séculos, a região gaúcha foi palco se sangrentos conflitos armados na ânsia de proteger o solo gaúcho e brasileiro, sem que o próprio Brasil reconhecesse a importância e a bravura do povo desta terra. $\mathrm{O}$ próprio território brasileiro foi aumentado pelos gaúchos, que disputaram palmo a palmo cada centímetro de terra contra o exército colonialista espanhol nos tempos do império. Foram sempre os gaúchos que se confrontaram com uruguaios, argentinos e paraguaios. (p. 52)

O gaúcho é reconhecidamente um exímio trabalhador em detrimento aos demais da federação, que são, em sua maioria escorados e amantes das praias do litoral. Como podemos notar, o dinheiro gaúcho sai da mesma forma. E pagamos muito caro por estes produtos. (p. 81)
\end{abstract}

Dessa forma, nos discursos intolerantes em geral, o destinador julga e/ou pune o destinatário que não cumpriu um acordo social; no discurso separatista, o destinatário considera que, como não há a contrapartida do destinador, o contrato deve ser rompido, pois é ruim para ele, que dá muito e recebe pouco: os gaúchos trabalham e os demais brasileiros se aproveitam do trabalho dos gaúchos. Esse é, sem dúvida, um dos traços característicos da narrativa separatista, o da ruptura de um contrato pelo destinatário que, em alguma ocasião quis o acordo ou foi obrigado a aceitá-lo, mas que, mais tarde, o considera insatisfatório e se propõe a rompê-lo.

Outras narrativas separatistas corroboram essa questão, como, por exemplo, o discurso separatista paulista, em 1932 ou atualmente, que ressalta sempre o muito que São Paulo faz pelo país e o pouco que recebe de volta. Em suma, aquele que quer separar-se considera o acordo benéfico para a outra parte apenas.

Outra característica da narrativa separatista, além da ruptura de contrato, é, conforme apontado, a de se apresentar como uma narrativa de resistência à intolerância do outro.

O sujeito separatista, nesse caso, reage à sanção negativa do destinador e, como forma de resistência à intolerância, propõe a separação: 
BARROS, Diana Luz Pessoa de. A identidade intolerante no discurso separatista

\begin{abstract}
Por este motivo, este livro busca iniciar de vez de forma organizada e concreta um movimento separatista de libertação regional, com um novo alento, com responsabilidade, mas que de forma alguma incita à violência armada, pois sabe que violência gera violência, perseguições, tentados geram atentados, e a morte, as atrocidades, carnificinas e outros males consequientes, só devem vir em agrado dos que dominam o povo ao seu bel prazer. Nosso movimento, em primeira instância, deve ser pacífico, sadio, respeitador dos direitos humanos, buscando, de forma legitimada, conquistar a sua independência. Mas não seremos cordeiros que normalmente são conduzidos para o matadouro e sacrificados sem nenhuma defesa. (p. 7-8)
\end{abstract}

A separação não é a divisão do país-totalidade (totus) em partes, mas conforme apontamos no trabalho já citado (Barros, 1992), o recorte da parte diferente. As noções de diferença e identidade caracterizam o discurso de resistência, que reforça e valoriza a identidade e trata de mantê-la.

O sujeito separatista cumpre, portanto, dois papéis narrativos: sanciona negativamente o destinador que não cumpriu o acordo e pune esse destinador com a ruptura do contrato; reage à sanção intolerante a que é submetido por ser "diferente" (e dessa forma não estar cumprindo o contrato estabelecido) e propõe a separação como uma forma de resistência à intolerância e de conservação de suas "diferenças", de sua identidade. Em alguns discursos separatistas, o discurso de resistência à intolerância e de afirmação da identidade assume as características do discurso terrorista.

Retomando o trabalho de Eric Landowski, Présences de l'autre (1997), pode-se dizer, nesse caso, que o sujeito separatista não aceita nem ser assimilado e perder identidade, nem ser agregado, pois se considera discriminado por ser "diferente".

O discurso da diferença se, por um lado, é próprio dos discursos de resistência, por outro é o lugar do dialogo com outros tipos de discursos intolerantes, no caso do separatismo gaúcho, sobretudo os de intolerância racial e linguiística, conforme apontado acima (ver Barros, 1992) e desenvolvido em outras etapas deste artigo: 
Filol. linguiíst. port., n. 9, p. 147-167, 2007.

\begin{abstract}
Afora santa Catarina, que também se desenvolveu por suas próprias forças que respeitamos a adoramos e queremos que se junte a nós neste movimento, nada temos em comum com praticamente todo o Brasil, que nos faz engolir à força a cultura de outras regiões, minando e confundindo nossos costumes, tirando a nossa própria identidade e maneira de ser. Temos a nossa própria e secular tradição, nossos próprios costumes. Pretendemos avançar no tempo, conservando nossos hábitos, mas buscando na ciência, na informática, na educação, na saúde, na habitação, nos investimentos da área agrícola, do trabalho, da tecnologia, nos projetos espaciais e futurísticos, mais garantia e respeito para nossos filhos, para nossos netos e para a própria civilização gaúcha. (p. 55)

$\mathrm{O}$ pangauchismo se faz presente em todas as partes, conservando suas tradições, suas indumentárias, sua cuia e seu chimarrão. O povo gaúcho se difere dos demais a olhos vistos, e por onde anda deixa a sua marca de homem íntegro e valente. (p. 82)
\end{abstract}

Em síntese, a narrativa separatista é uma narrativa de sanção em que o destinatário sujeito julga negativamente o destinador que não cumpriu a sua parte do acordo e o pune com a ruptura do contrato e, também, uma narrativa de ação, ou de reação e resistência à intolerância do outro, em que se busca como valor a conservação das diferenças, a preservação da identidade.

\title{
2.2. As paixões separatistas
}

A semiótica constrói os percursos passionais dos discursos com base nos estudos da modalização e da aspectualização discursivas.

As hipóteses sobre a constituição dos percursos passionais dos discursos intolerantes são a de que os sujeitos intolerantes são sempre sujeitos apaixonados e a de que predominam nesses discursos as paixões ditas malevolentes (antipatia, irritação, ódio, raiva) ou de querer fazer mal ao sujeito que não cumpriu os acordos sociais, tais como examinados no item anterior, mas também a paixão benevolente do patriotismo ou do querer fazer bem à pátria. 
O percurso passional é, assim, o que foi descrito por Greimas (1983) em seu estudo sobre a cólera. O sujeito parte de um estado inicial de espera confiante, em que quer conseguir certos valores e acredita que outro sujeito fará com que ele os obtenha. Ao tomar conhecimento de que isso não acontecerá, ou seja, de que aquele em quem confiou nada fará para que ele consiga os valores desejados ou mesmo fará com ele não os obtenha, o sujeito sofrerá as paixões da decepção e da frustração e, com o crescimento da tensão, as do desespero e da insegurança. Sem os valores almejados e em crise de confiança, o sujeito procurará resolver sua falta e passará a querer fazer mal a quem o colocou, segundo o simulacro construído, nessa situação (Barros, 1990). A malevolência parece ser o caminho para que as coisas sejam postas em seus "devidos lugares", mesmo que a falta primeira não se resolva com isso. Vejam-se, por exemplo, as recentes reações de malquerença da sociedade brasileira aos casos de violência bárbara contra crianças. As paixões malevolentes variam de intensidade - antipatia, irritação, raiva, ódio - e são as que caracterizam, no domínio do público, a xenofobia, por exemplo. Nesse mesmo âmbito, a paixão contrária é a do patriotismo, em que se quer fazer bem à pátria. Em geral, o sujeito do ódio em relação ao estrangeiro, ao diferente, aos "maus" usuários da língua, é também o sujeito do amor à pátria, à sua língua, ao seu grupo étnico, aos de sua cor, à sua religião. É esse jogo entre o querer fazer mal e o querer fazer bem que caracteriza passionalmente o sujeito apaixonado intolerante:

Só devem permanecer no PAMPA aqueles que querem uma pátria melhor, com melhores possibilidades de sucesso pessoal e patriótico. Ame o PAMPA como a si mesmo, ou deixe-o para sempre! (p. 77)

Temos procurado em nosso grupo de pesquisa sobre a intolerância linguiística (ver trabalhos de Leite, 2005 e Bueno, 2006) distinguir duas etapas nos percursos passionais do sujeito intolerante. A primeira é a que acabamos de descrever, aquela em que o sujeito se torna malevolente em relação ao outro, que, "diferente", não cumpriu o contrato de identidade (como destinador ou como destinatá- 
rio), e benevolente em relação à pátria, aos iguais, aos idênticos. Essa primeira etapa, a mais passional da intolerância, é a do preconceito.

A segunda fase, a da intolerância propriamente dita, é aquela em que o sujeito preconceituoso (decepcionado, frustrado, desesperado, inseguro e que tem ódio) passa à ação, ou seja, completa sua competência e age contra o outro (o causador da falta, o odiado). Greimas, no texto citado (1983), propõe, nesse caso, as ações apaixonadas de vingança ou de revolta.

No discurso separatista, o sujeito que causou a decepção, a frustração, o desespero e a insegurança no gaúcho é o destinador Brasil, que passa assim a ser alvo das paixões malevolentes de ódio, de raiva desse sujeito. É contra o destinador Brasil também que o gaúcho se revolta. A proposta e o encaminhamento da separação constituem a ação da revolta, seja como uma punição ao destinador que não cumpriu sua parte no acordo, seja como uma ação de resistência aos preconceitos e intolerâncias sofridos e de recuperação da falta para a retomada de uma nova espera confiante:

\footnotetext{
O livro não deixa de ser uma verdadeira denúncia às calamidades, às discriminações berrantes que nos circundam. Num cômputo geral, temos uma noção básica do que ocorre em nosso meio, nossos sonhos, nossas esperanças, nossas ambições, nossos problemas e conflitos. (p. 7) Por outro lado é visível o descontentamento que reina entre o povo gaúcho pela atual situação vigente. Os ideais farroupilhas voltam à tona, e o espírito de valentia, da liberdade, do inconformismo, por estar sendo governado por seres inferiores a nossa cultura, faz bater cada vez mais forte o coração idealista e sem igual do povo gaúcho. (p. 7)
}

De novo, no exame das paixões, as especificidades do discurso separatista são facilmente identificadas: o discurso separatista coloca-se no domínio das paixões que envolvem sujeitos coletivos, pois é contra o Brasil que os gaúchos se revoltam e a ele resistem e é o povo gaúcho que é amado e construído como pátria; há, no discurso separatista, a resistência, também apaixonada, contra as paixões do preconceito e da intolerância e fortes manifestações de ódio e de amor (patriotismo); as duas etapas são claras, a do pre- 
BARROS, Diana Luz Pessoa de. A identidade intolerante no discurso separatista

conceito e a da intolerância, conforme a caracterização proposta desses conceitos.

\subsection{A pessoa no discurso separatista}

Os usos discursivos das categorias de pessoa, de tempo e de espaço estabelecem as relações de aproximação e distanciamento entre o discurso e as instâncias de sua enunciação e entre enunciador e enunciatário. Neste artigo, são examinados apenas os recursos de pessoa.

O discurso separatista gaúcho é projetado em primeira pessoa ou de forma enunciativa, no dizer da semiótica. Dessa forma, o discurso produz os efeitos de sentido de aproximação da enunciação e de comprometimento e cumplicidade com o destinatário.

Esses efeitos de subjetividade são, porém, fortemente atenuados por duas estratégias discursivas: o uso da terceira pessoa em lugar da primeira e o emprego da primeira pessoa do plural em vez da primeira do singular. Alternam-se os dois procedimentos, ou seja, o "eu" é substituído por "o autor" e por "nós". O uso da terceira pessoa em lugar da primeira mantém, de alguma forma, o efeito de aproximação, mas somado a uma certa objetividade e afastamento. Observem-se os trechos que seguem:

É da intenção do autor seguir uma linha reformista, tentando de todas as formas, apresentar um substituto eficaz para o sistema social, cultural, político e religioso que tão mal nos rege. (p. 7)

$\mathbf{0}$ autor não pretende ser considerado uma pessoa sensacionalista e sim, alguém disposto a dar tudo de si em benefício da comunidade gaúcha. (p. 9) $\mathbf{O}$ autor espera que em cada localidade se criem os comitês do movimento separatista. (p. 9)

Assim sendo, o autor lhe deseja uma boa e proveitosa leitura. (p. 11) 
A primeira pessoa do plural é usada no discurso separatista em dois casos: em lugar da primeira do singular, como nós de autor, o que atenua um pouco a subjetividade do discurso; como nós misto, que inclui o destinador, o destinatário e os gaúchos, e cria identificação entre eles, confundindo-os. Os trechos abaixo citados exemplificam as duas situações:

\footnotetext{
Para que o leitor fique um pouco mais estarrecido vamos apresentar o nome de alguns países cujos territórios são muito menores do que alguns municípios do PAMPA. (p. 124)

Num cômputo geral, temos uma noção básica do que ocorre em nosso meio, nossos sonhos, nossas esperanças, nossas ambições, nossos problemas e conflitos (...). Enfim temos perdido a todo momento as esperanças de mudar o atual contexto estando nas mãos dos brasileiros e de outras pessoas inescrupulosas. (p. 7)
}

O uso da primeira pessoa para o destinador do texto, ainda que atenuada como o autor ou nós, instala obrigatoriamente a segunda pessoa do destinatário, de forma implícita ou explicita, o que produz a ilusão de cumplicidade e de reciprocidade.

No discurso separatista em exame, o destinatário, quando explicitado, aparece como você ou atenuado como o leitor. $\mathrm{O}$ uso de você reforça a cumplicidade subjetiva e o equilíbrio dos papéis recíprocos de destinador e destinatário; o emprego de o leitor cria um certo afastamento, sem, porém, apagar o comprometimento entre autor e leitor. As citações que seguem mostram os dois usos e a alternância entre eles, às vezes no mesmo parágrafo:

Para que o leitor se coloque bem mais a par da situação, compare o tamanho do seu município com os outros e com o território dos países acima relacionados (p. 125)

Se você é predisposto às lutas corporais, às maldades, cuidado, pois está no seu cérebro a descendência direta dos ancestrais. (p. 206)

E você como tem procedido no seu dia-a-dia? (p. 223) (frase que encerra o livro). Neste livro, o leitor encontrará uma linguagem muito simples, sem expressões difíceis que só confundiriam a opinião pública (p. 9)

Deste já, o autor sente o interesse do leitor para tomar ciência destas infor- 
BARROS, Diana Luz Pessoa de. A identidade intolerante no discurso separatista

mações. (...) Você verá, passados alguns dias, que o entendimento chegará e que a sua inteligência começará a discernir o que está escrito. (p. 9)

Quer queira ou não, o leitor se verá transportado para outro mundo. (...) Descobrirá a sua verdadeira personalidade. Quem você é. (p. 10)

É preciso ainda observar que os gaúchos empregam tu, e não você, e que, para eles, o uso de você é mais distanciado, menos íntimo do que o do $t u .^{2}$

Em síntese, pode-se concluir que o discurso separatista em exame constrói de forma enunciativa as pessoas do discurso (eu-tu), produzindo efeitos de subjetividade e de cumplicidade entre o destinador e o destinatário, mas o faz com recursos de atenuação nós e $o$ autor vs você e o leitor. Em outras palavras, o efeito é de alternância entre a subjetividade mais passional e a objetividade mais racional, para criar a imagem de um destinador sensível, mas que vê as questões com isenção e conhecimento. Da mesma forma, os laços de cumplicidade e comprometimento com o destinatário se mantêm, mas a intimidade e a igualdade entre eles são atenuadas pelo uso de você e o leitor.

O destinatário que aparece ora como você, ora como o leitor é, em geral, preenchido no texto pela figura do gaúcho, que está sendo instado a participar do movimento. Em alguns momentos, o destinador dirige-se ao povo de Santa Catarina, para colocá-lo também no movimento, em outros, aos políticos (em terceira pessoa), para com eles polemizar. $O$ autor ou o nós, por sua vez, fala pelo governo da República do Pampa Gaúcho.

A relação entre o destinador e o destinatário é, como foi visto, construída como uma relação de subjetividade e cumplicidade atenuadas.

2 Outra possível interpretação do uso de você e não do tu foi-me sugerida por José Gaston Hilgert: entre os gaúchos é usado $o$ tu na fala coloquial com o verbo na $3^{\circ}$ pessoa, mas esse emprego produz o efeito de incorreção; o emprego do verbo na $2^{\circ}$ pessoa teria o efeito de correção, mas também o de excesso de formalidade; o uso de você ficaria a meio caminho entre o excesso de informalidade, popularidade e incorreção e o excesso de formalidade e distanciamento. 
Deve-se observar que, se as estratégias que envolvem as pessoas do discurso produziram efeitos, sobretudo, emocionais, outros procedimentos foram usados para a criação de efeitos predominantemente racionais, tornando, assim, o discurso separatista bastante equilibrado entre a paixão e a razão. Podem-se mencionar, entre outras estratégias:

- a comparação com outros países, de mesmo tamanho ou mesmo menores do que a nova república proposta;

- o emprego de dados numéricos (extensão, população, aspectos econômicos etc.), gráficos, tabelas, mapas;

- a apresentação mais concreta (com figuras) dos aspectos gerais, sobretudo econômicos, da nova república (bandeira, capital, limites, população, número é nomes dos municípios, principais atividades econômicas, dados sobre propriedades rurais, e até o numero de telefones...);

- a comparação com outros movimentos separatistas (basco, corso etc.);

- o uso de fotos e reportagens, em geral sobre a miséria em que vive o gaúcho, apesar das riquezas do Estado.

Esses procedimentos produzem em geral afeitos de realidade e, em decorrência, de verdade, tornam o destinador confiável e levam o destinatário à credibilidade.

\subsection{Os temas e figuras no discurso separatista}

É no nível de análise dos temas e figuras que a ideologia e as determinações sócio-históricas se manifestam mais claramente (Fiorin, 1988). 
Os discursos intolerantes podem ser tanto discursos apenas temáticos, com figuração esparsa, quanto discursos temático-figurativos, com mais recursos sensoriais.

Os discursos separatistas em exame são temáticos, com figuras ocasionais que não estabelecem relações de coerência figurativa.

Os principais temas desenvolvidos são:

- tema socioeconômico do desenvolvimento, que toma duas direções, uma delas com a moralização do tema do crescimento: o Rio Grande do Sul é mais desenvolvido e rico do que o resto do país, e essas riquezas precisam ser conservadas; a seriedade e o trabalho dos gaúchos fazem crescer essas riquezas, ao contrário do que acontece no resto do país;

- tema político da ingovernabilidade: os maus políticos e o governo são, em boa parte, os responsáveis pelo fraco desenvolvimento do país, pela distribuição injusta de renda entre os estados, pelo descontentamento dos gaúchos; o tamanho do país torna-o ingovernável;

- tema histórico, também em duas perspectivas: os gaúchos têm tradição de luta, são descendentes dos farroupilhas e precisam honrar essa história; a história mostra que na modernidade os grandes países estão sendo fragmentados com bons resultados;

- tema da diferença e da identidade: os gaúchos são diferentes dos brasileiros e melhores do que eles, do ponto de vista histórico, cultural, étnico e ético, o que leva ao tema do racismo - tanto o do racismo discriminatório, quanto o do racismo diferencialista necessário à construção do discurso separatista, e ao do narcisismo, entendido como a valorização e a busca excessivas da identidade (Fiorin, 1994, p. 221-2); 
Filol. linguiíst. port., n. 9, p. 147-167, 2007.

- tema da separação: o tema da separação aparece como o da ação de revolta contra os maus, em todos os aspectos (histórico, moral, étnico, cultural etc.), como o da realização dos sonhos de crescimento (cultural, ético, socioeconômico, político) dos bons, e como uma necessidade histórica; o tema da separação constrói um discurso maniqueísta em que bem e mal se contrapõem, com a vitória do bem, o que, de uma certa forma, justifica todas as ações empreendidas, como ocorre nos discursos terroristas.

O discurso separatista apresenta-se como um discurso inovador, mas se coloca, nos percursos temáticos, como um discurso construído com valores conservadores (maniqueísmo, racismo, moralismo etc.).

\subsection{Diálogos do discurso separatista com outros discursos}

O discurso separatista mantém diálogos polêmicos ou contratuais com outros discursos sociais. O exame desses diálogos complementa o quadro de valores em que o discurso separatista se insere e sua determinação sócio-histórica.

Em primeiro lugar, deve-se observar que o discurso separatista se constrói na interseção de vários discursos intolerantes: o discurso racista, o discurso de intolerância linguiística e o de intolerância religiosa. Ao mesmo tempo, se apresenta como um discurso de reação às intolerâncias socioculturais e políticas sofridas pelos que querem se separar.

Em segundo lugar, o discurso separatista gaúcho dialoga polemicamente e de forma explícita com os discursos políticos, da direita e da esquerda no Brasil, e com os discursos das várias religiões, e contratualmente, ou seja, para com eles concordar, com o discurso científico, em geral, e histórico, em particular, e com os 
discursos moralistas das camadas médias da população. É nessa encruzilhada que se constroem seus valores, conforme as citações que seguem:

\begin{abstract}
No nosso entendimento, a religião, seja ela qual for, está sendo alcançada pela história, que expõe seus erros e pecados, seus enganos e desilusões, as boas e as más ações, dela mostra suas obras e relíquias, que se expandiu pelo mundo pela força das espadas e dos fuzis e, principalmente, aponta em direção aos que a observam atentamente como fonte de informações e de sabedoria, e que voltam, por conseguinte, suas costas aos danos e às consequiências maiores que as religiões já cometeram ao longo da sua história. E hoje, em que pese a contestação dos mais fanáticos, as religiões continuam persuadindo e dominando a mente dos menos esclarecidos. (p. 22)

A Igreja talha os direitos individuais pior do que as ditaduras de esquerda ou de direita, pois ela toca nas emoções do homem. Ela condiciona o ser humano a uma robotização total, com propósitos voltados ao fortalecimento da empresa-religião, que embora não deixe transparecer é mais materialista que se possa imaginar. (p. 23)

Num cômputo geral, a classe política é interesseira e inescrupulosa e não dá a mínima atenção aos seus eleitores, salvo, é claro, aos seus importantes cabos eleitorais. (p. 25)

Em meio a esta desorganização urbana, agrícola e humana, temos visto gente mais parecendo animais do que seres racionais. Alguns até andam chapados 24 horas por dia, não produzindo nada a não ser encrencas e andam com cada tipo de roupas, cabelos engomados, e fazem poses diferentes para sentar-se nas calçadas de uma cidade. Só vendo para acreditar. São os chamados metaleiros, hippies, vagabundos, ou o isto ou o aquilo. Estão iludidos com os filmes tipo Mad Max e outros. (p. 43)
\end{abstract}

Mas esta é uma história que se repete após quase dois séculos de derrota farroupilha. Os farrapos ergueram-se em armas contra a espoliação e exploração vinda lá de cima e se confrontaram com os soldados brasileiros. (p. 79)

\title{
CONSIDERAÇ̧̃ES FINAIS: A IDENTIDADE INTOLERANTE SEPARATISTA
}

O ethos do enunciador, tal como foi retomado da retórica na perspectiva da semiótica discursiva, constrói-se como um ator da enunciação, a partir de um conjunto de discursos (Discini, 2005 e Fiorin, 2004). No caso em exame, essa totalidade é formada pelo 
conjunto de textos que compõem o livro de Irton Marx, e a analise dos procedimentos linguiístico-discursivos desse conjunto de textos leva a que se esboce a identidade do sujeito separatista neles construída.

A partir de Aristóteles (1991) e dos estudos de Maingueneau (1995) e Fiorin (2004) podem-se examinar nos textos três tipos de ethe do enunciador;

- o primeiro, construído pela dimensão racional e inteligível dos textos, é o de um enunciador competente, capaz, que diz a verdade e deve levar o enunciatário à credibilidade, à confiabilidade, à crença;

- o segundo, criado nas dimensões do inteligível e do emocional (do ethos propriamente dito), é o do enunciador corajoso, justo;

- o terceiro, resultante da dimensão passional e sensorial dos textos, é o do enunciador benevolente, cúmplice.

O ethos separatista é assim:

- no primeiro caso, um ethos marcado pela atividade, isto é, pela competência e veracidade construídas com discurso científico e histórico, com números, mapas, tabelas, e pela luta - ethos beligerante, revoltoso;

- no segundo caso, um ethos corajoso, de um sujeito que se expõe contra a Igreja ou o governo, mas na justa medida, não é temerário (como, por exemplo, nos enunciadores excessivos dos discursos separatistas terroristas);

- no terceiro caso, um ethos subjetivo - indignado, descontente, malevolente, intolerante, nunca resignado - e cúmplice - fortemente patriótico e benevolente com os seus iguais. O discurso separatista constrói, assim, um sujeito competente, capaz, confiável, beligerante, lutador, corajoso, indignado, intolerante e patriótico. É essa imagem que procura passar a seu enunciatário. 
BARROS, Diana Luz Pessoa de. A identidade intolerante no discurso separatista

No âmbito da intolerância, ponto de partida deste estudo, o discurso separatista apresenta, como se procurou mostrar, características próprias de organização narrativa, discursiva e intertextual, e, portanto, de diferenciação de identidade, e seu exame contribui com a construção de um conhecimento mais fundamentado dos discursos intolerantes.

\section{BIBLIOGRAFIA}

ARISTÓTELES (1991) Rhétorique. Paris: Librairie Générale Française.

BARROS, D. L. P. de. (2005) O discurso intolerante: primeiras reflexões. São Paulo (texto digitado).

. (1995) Preconceito e separatismo no discurso: um discurso separatista gaúcho. Organon, 9, 23, p. 199-204.

. (1990) Paixões e apaixonados: exame semiótico de alguns percursos. Cruzeiro Semiótico, 11/12, p. 60-3.

BUENO, A. M. (2006) Intolerância lingüística e imigração. Dissertação (Mestrado) - Universidade de São Paulo.

DISCINI, N. (2003) O estilo nos textos: história em quadrinhos, mídia, literatura. São Paulo: Contexto.

FIORIN, J. L. (2004) O ethos do enunciador. In: CORTINA, A.; MARCHEZAN, R. C. (orgs.). (2004) Razões e sensibilidade: a semiótica em foco. Araraquara: Laboratório Editorial/FCL/ UNESP/ São Paulo: Cultura Acadêmica.

. (2002) As astúcias da enunciação. As categorias de pessoa, espaço e tempo. 2. ed. São Paulo: Ática.

. (1994) Preconceito e separatismo. Boletim da Associação Brasileira de Lingüística, 15, p. 217-22.

. (1988) Linguagem e ideologia. São Paulo: Ática.

GREIMAS, A. J. (1983) Du sens II. Paris: Seuil.

GREIMAS, A.J.; COURTÉS, J. (1979) Sémiotique. Dictionnaire raisonné de la théorie de langage. Paris: Hachette.

LANDOWSKI, E. (1997) Présences de l'autre. Paris: Presses Universitaires de France..

LEITE, M. Q. (2005) A intolerância lingüística na imprensa. São Paulo (texto digitado).

MAINGUENEAU, D. (1995) O contexto na obra literária. São Paulo: Martins Fontes.

MARX, I. (1990) Vai nascer um novo país: República do Pampa Gaúcho. Santa Cruz do Sul: Excelsior. 
Filol. lingüíst. port., n. 9, p. 147-167, 2007.

ABSTRACT: This paper presents some results obtained by the investigation of the discursive construction of the intolerant identity, developed within the Laboratory of Studies on Intolerance. The theoretical framework is that of French discursive semiotics. The objective of the paper is to show how intolerant (racist, fascist, secessionist) discourses are built, and what identity (the intolerant ethos) is built therein. This is done by the investigation of linguisticdiscursive procedures, and of the ethical frame within which these discourses are built. This article deals specifically with secessionist discourse, which is a type of intolerant discourse.

KEYWORDS: Intolerant discourse; secessionist discourse; enunciator ethos; French discursive semiotics. 